LEBER, .T-Graefe-Saemisch Handb., Vol. VII (pt. 2), p. 1105, 1916.

MAGNuSson, H.-Arch.f.vergl.Ophthal., Vol. II, p. 147, 1911; Arch.f. Ophthal., Vol. XCIII, p. 404, 1917.

Nettleship.-Roy. Lond. Ophthal. Hosp. Repts., Vol. XVII, 1907.

OSTERBERG, G.-Thesis, “Topography of the layer of rods and cones in the human retina." Copenhagen University, 1935.

REDSLOB, E.-Ann. d'Ocul., Vol. CLXX, p. 140, 1933.

Stоск, W.-Klin. Monatsbl. f. Augenheilk., Vol. XLVI, (1), p. 225, 1908.

TANSLEY, K.-Brit. Jl. of Ophthal., Vol. XVII, p. 321, 1933.

VERHOEFF, F. H.-Arch. of Ophthal., Vol. V (N.S.), p. 392, 1931.

Walls, G. L.-Jl. Comp. Psychol., Vol. XVIII, p. 363, 1934.

YATAKA, T.-Acta Soc. Ophthal. Jap., Vol. XXXIX p. 264, 1935 (quoted from Zentralbl.f.d.ges. Ophthal.), Vol. XXXVI, 1936.

Acknowledgements.-We are indebted to the Medical Research Council, the Birmingham and Midland Eye Hospital and the Brit. Jl. of Ophthal. for the financial assistance which made this work possible. We are greatly indebted to Dr. R. J. Lythgoe for taking the photographs of the retinal sections and to Miss $M$. Marshall for preparing many of the sections.

\title{
ANNOTATION
}

\section{Protection of Welding Workers Employed in the Mines}

We have received a report on this subject by a sub-committee of the Prevention of Accidents Committee of the Rand Mutual Assurance Co., Ltd., S. Africa. This sub-committee was instructed to review and bring up to date the recommendations made in March, 1932, with a view to protection of welding workers.

The principal hazard connected with welding is that due to the generation of ultra-violet and infra-red rays by the oxy-acetylene flame or by the arcs used in electric welding processes. The former are of short wave length and high penetrative power; the latter are of long wave length and no great penetrative power. Both are capable of damaging the eye.

The intensity of ultra-violet rays is proportionate to the amperage used in the electric welding process. The oxy-acetylene flame is relatively weak in these rays. Methods of eye protection must, therefore, vary with the intensity of the amperage used. And in connexion with welding there is danger from sparks and particles of metal either entering the eyes, setting clothes on fire, or burning the skin.

The following are the main subsections of this valuable report:-

1. INCIDENCE OF ACCIDENTS.

The Sub-Committee notes with satisfaction that since the issue of its circular in March, 1932, great advance has been 
made in the protection of welding workers on the mines, with the result that no serious accident has occurred and relatively few even minor accidents during the past five years. This is reflected in the subjoined summary of replies to questionnaire issued by the Sub-Committee.

2. Methods of Protection Recommended:

(a) Oxy-acetylene welding.

Adequate protection for the eyes can be provided by using goggles with special light absorbing lenses. The goggles should make a close fit to the eye sockets all round, so as to avoid rays or sparks entering around the frames. Proper fitting of the goggles is of the utmost importance, as accidents have been caused by goggles which did not make a close fit to the face. Helmets of an approved type, referred to below, are more satisfactory than goggles.

(b) Metallic electrode welding.

(i) A.C. Under 100 amperes.

Approved helmets with light absorbing glass, of a type which will absorb all ultra-violet radiation and at least 99 per cent. of the infra-red.

Aprons with high-fitting bibs, so as to protect the neck.

Gloves so as to protect the hand, wrist and forearm.

(ii) A.C. 100 aimperes and over.

As under heading $2(b)$ (i). In addition each operator should be surrounded by a screen painted inside with a lead paint of a dark, flat colour. Where others than welders are likely to come close to welding operations, their eyes should be protected with goggles, of the type described under $2(a)$ hereof.

(iii) D.C.

The same protection as described in $2(b)$ (ii).

(c) Butt welding.

- The same protection as described in 2 (b) (ii).

(d) General.

(i) All partitioned portions of buildings surrounding welding operators should be well ventilated, and at the same time be of sufficient height to protect passers-by, i.e., the height should be not less than $7 \mathrm{ft}$. Where partitions are used on temporary work outside the welding shop they should be so erected as to ensure complete isolation to persons employed on other work in the vicinity. 
(ii) Aprons should be made of leather, asbestos, or such other material as will protect the clothing of the operator from sparks, and also have a high bib so as to protect the neck. There should be no external pockets on the apron, and workers who do not use an apron should be specially warned about having external pockets in their clothing into which sparks might enter.

(iii) Gloves should be of the gauntlet type, and the sleeves of the shirt or coat should be tucked inside the gloves.

Suitable types of goggles and helmets with ultra-violet and red absorbing glass are available for inspection at the office of the Secretary, The Prevention of Accidents Committee, P.O. Box 413, Johannesburg, from whom all particulars can be obtained.

As an appendix there are printed in tabular form the replies received from 55 gold, 14 coal and 3 other mining companies and from the Hume Steel S.A. (Pty.), Ltd., with a note of the protective measures adopted by many of the companies against electric shock. It is of interest to note that from the replies received it appears that arising out of the use of welding apparatus 73 companies, with a total of 353 welding machines of all types and employing 413 whites and 432 natives, there have been (with the exception of cases of tired or sore eyes, headaches, and, in the case of one company, occasional burning with oxy-acetylene) only two accidents during the period covered by this enquiry.

No mention seems to be made in this report of the reflecting type of glass suggested some years ago by Imre of Budapest. These glasses have the great advantage of not absorbing the light and turning it into heat. They can be obtained in any degree of density and are made with a gold or a platinum reflecting surface. The former gives a green colour and the latter, a grey when looked through.

\section{ABSTRACTS}

\section{I.-LENS}

(1) Goldmann, H. and Liechti, A. (Berne).-Experimental research on the causation of X-ray. cataract. (Experimentelle Untersuchungen ueber die Genese des Röntgenstars). Arch. f. Ophthal., Vol. CXXXVIII, p. 722.

(1) Experiments performed on rabbits and here recorded by Goldmann and Liechti, showed that, contrary to the views of some 